\title{
Information Communication Technologies in Atrocity Response and Prevention: Deepening Our Understanding of the Legal, Ethical and Practical Challenges
}

Charles Martin-Shields

Deutsches Institut für Entwicklungspolitik

Follow this and additional works at: https://digitalcommons.usf.edu/gsp

\section{Recommended Citation}

Martin-Shields, Charles (2017) "Information Communication Technologies in Atrocity Response and Prevention: Deepening Our Understanding of the Legal, Ethical and Practical Challenges," Genocide Studies and Prevention: An International Journal: Vol. 11: Iss. 1: 100-103.

DOI:

http://doi.org/10.5038/1911-9933.11.1.1484

Available at: https://digitalcommons.usf.edu/gsp/vol11/iss1/10

This Symposium on the State of the Field is brought to you for free and open access by the Open Access Journals at Digital Commons @ University of South Florida. It has been accepted for inclusion in Genocide Studies and Prevention: An International Journal by an authorized editor of Digital Commons @ University of South Florida. For more information, please contact digitalcommons@usf.edu. 


\title{
Information Communication Technologies in Atrocity Response and Prevention: Deepening Our Understanding of the Legal, Ethical and Practical Challenges
}

\author{
Charles Martin-Shields \\ Deutsches Institut für Entwicklungspolitik \\ Bonn, Germany
}

\section{Introduction}

Much of the excitement in the past decade about the potential for new technologies such as mobile phones, wireless high-speed Internet, and social media software to aid in the prosecution of mass atrocities has evolved into deeper analysis of whether these tools can really do everything we thought possible. The development of the ICTs for atrocities research and response field is at a stage where praxis, the use of practice to inform the development of theory, is crucial. Deeper theory, grounded in empirical examples, can lead to better data collection and thus a better understanding of the impact of ICTs on atrocities response in both research and practice. This collection of articles theoretically and empirically pushes these issues further, building on existing policy and field experience to develop frameworks that can guide both empirical research and policy development for using ICTs in atrocities monitoring.

The articles in this Special Issue invite readers to think about how the relationship between digital technology and atrocities response has evolved over the past 15 or so years. Levinger's analysis of the United States Holocaust Memorial Museum's (USHMM) Crisis in Darfur and Amnesty USA's Eyes on Darfur offer a good starting point for understanding how the ICT for atrocities response field has developed. ${ }^{1}$ Specifically, we may ask how this evolution has created the need for better theoretical and practical frameworks for ethics, privacy, and technical acumen in the humanitarian and human rights communities. Levinger's examples of digital data collection on mass atrocities relied on commercial satellite imaging and trusted reporters on the ground. This method evolved rapidly in 2008 when Ushahidi, a mapping and crowdsourcing platform, was designed in a matter of days in Kenya to allow citizens to report on violence via text message. The messages could then be coded and visualized on a map for the public to see. This piece of software, developed by a small group of Kenyan lawyers, journalists, and developers to gather local data and provide a voice for Kenyans affected by the violence, brought the process of crowdsourcing, big data, and ICTs to humanitarianism's center stage. This shift to using data submitted by the public via mobile phone and social media introduced a host of ethical, risk management, institutional, and legal issues, many of which we are only fully grasping nine years after Ushahidi was initially deployed.

This context raises serious thematic and methodological questions regarding how we study the role of ICTs in mass atrocities response. The theme is inherently cross-cutting: within this collection of articles are references to law, political science, anthropology, public administration, and informatics with a particular focus on the need for a corresponding pedagogy to learn about data collection through the use of ICTs to respond in distinct phases of mass atrocities. ${ }^{2}$ The mix of fields makes defining a driving research methodology difficult. Indeed, it could very well be that there is not yet enough data available to measure the causal impact of ICTs on mass atrocities response. Nathaniel Raymond and Kristin Bergtora Sandvik's contribution to this collection focuses instead on establishing ethical norms for engaging in the scientific process of using population-generated data to better understand the impact of ICTs on localization outreach as well as developing new tools and methods for data gathering. ${ }^{3}$ Theirs is a concern pertaining to risk consciousness as ethical

\footnotetext{
${ }^{1}$ Matthew Levinger, "Geographical Information Systems Technology as a Tool for Genocide Prevention: The Case of Darfur," Space and Polity 13, no. 1 (2009), 69-76.

${ }^{2}$ Colette Mazzucelli and Anna Visvizi, "Querying the Ethics of Data Collection as a Community of Research and Practice The Movement toward the 'Liberalism of Fear' to Protect the Vulnerable," Genocide Studies and Prevention: An International Journal 11, no. 1 (2017), 2-8.

${ }^{3}$ Nathaniel Raymond and Kristin Bergtora Sandvik, "Beyond the Protective Effect: Towards a Theory of Harm for Information Communication Technologies in Mass Atrocity Response," Genocide Studies and Prevention: An International Journal 11, no. 1 (2017), 9-24.
} 
practice, which informs the articles in the Special Issue. The meta level argument is practically grounded in Karen Naimer, Widney Brown and Ranit Mishori's article on the MediCapt mobile phone application, which is used for gathering forensic evidence of sexual violence in conflictaffected contexts, namely, the Democratic Republic of Congo, with implications drawn for other areas in which Physicians for Human Rights is engaged in the field. ${ }^{4}$

The two articles converge in a challenging space: we can build technology applications that serve the technical function of data collection, coding, and storage; yet, what are the ethical steps and processes necessary to go from data collection to the inherently open process of scientific analysis and public peer-review? In 2013, the ICRC released its updated Professional Standards for Protection Work, which included specific processes and considerations for effectively and ethically gathering and using data collected via ICTs in conflict-affected and humanitarian contexts. ${ }^{5}$ This study represented a start; yet, given the complexity of the digital environment, we need to push farther. The methods, tools, and procedures that have guided human subject research for the last 50 years, while informative, are less well suited for managing the legal, ethical, and technical challenges that come with using ICTs in mass atrocities research. Raymond and Sandvik challenge readers to think more comprehensively about the ethics of using ICTs in atrocities research, pedagogy, and response. In this context, as the field expands, we may have the necessary normative and ethical bases to use the ICT-gathered data effectively for research and practice.

While Raymond and Sandvik make a theoretical argument for defining ethics that can feed back into the scientific process of understanding ICTs in atrocities response, Christoph Koettl focuses on the practical issues of how to use satellite and mobile phone data to gather more accurate information about atrocities. ${ }^{6}$ He outlines a very real challenge for NGO and human rights organizations: getting the correct information out to the policy makers and public while limiting the risk that an organization will report false information and damage its credibility. His analysis is both descriptive, in terms of techniques for using imaging and cellular phone video data to verify incidents, as well as instructional in that it explains the steps organizations can take to improve their own capacity for using these tools. The article speaks to a broader issue in the innovation for public good space: What do organizations that innovate in this space look like? Koettl discusses the need for training of staff; yet, for the wider field of atrocities research and response, a larger question persists in how organizations build staffs that have the technical know-how to use these tools effectively and safely. This builds on work by Martin-Shields which argues that a key aspect of effectively using ICTs in humanitarian organizations is training of staff. ${ }^{7}$ In a world where non-technical users have access to open source software, a key way to make sure data is ethically captured and analyzed is to build knowledge of best practices among non-technical staff.

Ethics and operations also require technology for gathering and archiving ICTs-gathered data. This is a space that has received less coverage in part because of the stove-piped nature of how we address mass atrocities. These stove pipes broadly include the research, advocacy, and legal fields. They aim to answer interrelated, yet different, questions: why do atrocities happen; what are the atrocities that are happening; and how do we prosecute future atrocities? Binding all these questions are the processes for gathering new data and then archiving data as evidence so that standards required for research, advocacy, and legal validity are met. Jay Aronson discusses the legal and informatics issues involved with archiving digital content on atrocities, exploring the important yet easily overlooked aspects of how digital archiving alters the underlying information

\footnotetext{
${ }^{4}$ Karen Naimer, Widney Brown and Ranit Mishori, "MediCapt in the Democratic Republic of the Congo: The Design, Development, and Deployment of Mobile Technology to Document Forensic Evidence of Sexual Violence," Genocide Studies and Prevention: An International Journal 11, no. 1 (2017), 25-35.

${ }^{5}$ ICRC, "Professional Standards for Protection Work," accessed January 20, 2017, https://www.icrc.org/eng/assets/files/ other/icrc-002-0999.pdf.

${ }^{6}$ Christoph Koettl, "Sensors Everywhere: Using Satellites and Mobile Phones to Reduce Information Uncertainty in Human Rights Crisis Research," Genocide Studies and Prevention: An International Journal 11, no. 1 (2017), 36-54.

${ }^{7}$ Charles P. Martin-Shields, “The Technologist's Dilemma: Ethical Challenges of Using Crowdsourcing Technology in Conflict and Disaster-Affected Regions," Georgetown Journal International Affairs 14, no. 2 (2013), 157-163.
} 
about a video, image or social media post. ${ }^{8}$ These kinds of informatics issues can prove crucial when an organization is trying to determine the location an image came from or establish a chain of custody during legal proceedings. In this way, Aronson's and Naimer, Brown, and Mishori's articles are thematically reflexive. Read in relation to each other, they improve our understanding of how to gather information and the issues that will arise when it is time to archive the data for later use.

Providing a bridge between Raymond and Sandvik's and Naimer, Brown, and Mishori's articles is Stefan Schmitt and Dallas Mazoori's contribution on the role of DNA technology in identifying victims of mass atrocities. ${ }^{9}$ Schmitt and Mazoori bring a legal approach to discussing and laying out the ethical standards that the state and response agencies must meet in order to serve the needs of victims and families. This article is compelling from an academic perspective since it lays out the complex legal issues around identification and data ownership. As a practitioner, their analysis spoke to me because its premise is based on what responders owe victims. Schmitt and Mazoori provide a micro-level argument pointing out that DNA data collection must lead to identification of the victim both for legal and humanitarian purposes. How does technology, whether it be DNA, sensors or satellite imaging, help humanitarians and governments achieve legal ends such as repatriation of the dead or the rights of families to know the truth about a victim's whereabouts? These are questions that can be asked at all levels of technology use in atrocities response and are best asked before developing a new tool or beginning a new data collection process. At times, especially when working with tech and data, it is easy to lose sight of the fact that we are dealing with traumatized societies and families; for humanitarians and responders the questions that Schmitt and Mazoori raise can help keep the focus on how best to support and provide for victims of atrocities and their families as well as their local communities.

What this Special Issue provides for those working in atrocities research and response are 1) new analyses of what we have learned over the past fifteen years using ICTs in our work as well as 2) new analytical and theoretical frameworks for how to continue moving the study of mass atrocities forward ethically and effectively in an increasingly digital environment. These articles, taken collectively, also demonstrate the inherent challenges with creating a unified stream of research in a field, which is, by nature, multidisciplinary. Indeed, what ICTs may be doing is easing those of us involved in research, advocacy, and response out of our stovepipes and into what is, at the moment, both a challenging discussion and a critical need for pedagogy about how to bring the best of our fields together in responding to mass atrocities. ICTs provide the liminal space for researchers and activists, for educators and technical experts, to collaborate while the shape of this space is still developing. This collection of articles provides multiple reflexive levels of theoretical and practical analysis for scholars, advocates, and technologists to learn from - and to bond over - as we continue to push for justice, accountability, and a necessary response to the ethical imperative of "never again."

\section{Bibliography}

Aronson, Jay D. "Preserving Human Rights Media." Genocide Studies and Prevention: An International Journal 11, no. 1 (2017): 82-99. http://doi.org/10.5038/1911-9933.11.1.1441

ICRC. “Professional Standards for Protection Work." Accessed January 20, 2017. https://www.icrc. org/eng/assets/files/other/icrc-002-0999.pdf.

Koettl, Christoph. "Sensors Everywhere: Using Satellites and Mobile Phones to Reduce Information Uncertainty in Human Rights Crisis Research." Genocide Studies and Prevention: An International Journal 11, no. 1 (2017): 36-54. http://doi.org/10.5038/1911-9933.11.1.1440

Levinger, Matthew. "Geographical Information Systems Technology as a Tool for Genocide Prevention: The Case of Darfur." Space and Polity 13, no. 1 (2009): 69-76. https://doi. org/10.1080/13562570902781249

\footnotetext{
${ }^{8}$ Jay Aronson, "Preserving Human Rights Media," Genocide Studies and Prevention: An International Journal 11, no. 1 (2017), 82-99.

9 Stefan Schmitt and Dallas Mazoori, "Jurisdiction, Privacy and Ownership: DNA Technology and Field Dynamics in Conflict Related Mass Fatalities," Genocide Studies and Prevention: An International Journal 11, no. 1 (2017), 55-81.
} 
Martin-Shields, Charles P. “The Technologist's Dilemma: Ethical Challenges of Using Crowdsourcing Technology in Conflict and Disaster-Affected Regions." Georgetown Journal International Affairs 14, no. 2 (2013): 157-163.

Mazzucelli, Colette and Anna Visvizi. "Querying the Ethics of Data Collection as a Community of Research and Practice The Movement toward the "Liberalism of Fear" to Protect the Vulnerable." Genocide Studies and Prevention: An International Journal 11, no. 1 (2017): 2-8. http://doi.org/10.5038/1911-9933.11.1.1493

Naimer, Karen, Widney Brown, and Ranit Mishori. "MediCapt in the Democratic Republic of the Congo: The Design, Development, and Deployment of Mobile Technology to Document Forensic Evidence of Sexual Violence." Genocide Studies and Prevention: An International Journal 11, no. 1 (2017): 25-35. http://doi.org/10.5038/1911-9933.11.1.1455

Raymond, Nathaniel and Kristin Bergtora Sandvik. "Beyond the Protective Effect: Towards a Theory of Harm for Information Communication Technologies in Mass Atrocity Response." Genocide Studies and Prevention: An International Journal 11, no. 1 (2017): 9-24. http://doi. org/10.5038/1911-9933.11.1.1454

Schmitt, Stefan and Dallas Mazoori. "Jurisdiction, Privacy and Ownership: DNA Technology and Field Dynamics in Conflict Related Mass Fatalities." Genocide Studies and Prevention: An International Journal 11, no. 1 (2017): 55-81. http://doi.org/10.5038/1911-9933.11.1.1452 